\title{
Is Debate a Useful Strategy in Enhancing the Reading Comprehension and Critical Thinking of Iranian EFL Learners?
}

\author{
Mojgan Rashtchi \\ Islamic Azad University North Tehran Branch, Iran \\ Email: mojgan.rashtchi@gmail.com \\ Fatemeh Sadraeimanesh \\ Islamic Azad University North Tehran Branch, Iran \\ Email: sadraei_f2008@yahoo.com
}

\begin{abstract}
Thinking critically refers to investigating the thinking process in order to explain understanding and making decisions that are more intelligent. Debate is one of the most essential strategies which can effectively promote critical thinking in a classroom. The aim of the present study was to investigate the impact of debate as a critical thinking strategy on reading comprehension ability as well as critical thinking of Iranian EFL learners. To achieve this goal, 55 learners at intermediate level were selected based on convenient sampling. The administration of the TOEFL test enabled the researchers to select 40 students whose scores on language proficiency fell within one standard deviation above and below the mean. Subsequently the two homogeneous groups were randomly assigned to a control and an experimental group. In the experimental group debates were used as the main strategy of the class whereas the control group followed the traditional reading procedures. The statistical analysis of the participants' scores on a reading comprehension test and Honey's critical thinking questionnaire (2005) through MANOVA indicated that the strategy had a significant impact on the reading comprehension and critical thinking abilities of Iranian EFL learners.
\end{abstract}

Index Terms — reading, critical thinking, language proficiency, critical pedagogy, debate

\section{INTRODUCTION}

Thinking, as a remarkable process in every day life, helps people solve their problems, make decisions, and achieve the goals that makes their life purposeful. To think critically is a natural human ability that supports discovering the waythinking operates (Chaffee, 2009). According to Santrock (2008), thinking has different functions including reasoning, forming concepts, thinking critically and creatively, making decisions, and solving problems. As Chaffee,(2009) argues, the main purpose of thinking critically is to make "more intelligent decisions" and a critical thinker is a person who has the ability to take a deep cognisance of the outside world, can make wise judgments, and reflect upon "important ideas" (p.43).A critical thinker tries to solve complex problems in different ways by asking important questions, gathering relevant information, determining findings, and communicating effectively (Paul \& Elder, 2006). Halpern (1996) defines critical thinking as the application of cognitive skills or strategies to enhance the chance of appropriate outcome.

The most efficient and developed vehicle for carrying out the process of thinking is language. For Mangel (2005), language is placed under the element of thought. Halpern (1996) seeslanguage as a medium to express one's thoughts and signifies comprehension as the most critical reason for language use.

Language skills in general and reading skill in particular, as Mangel (2005) argues, involve comprehension and thus stimulation of thinking. According to Richards and Schmidt (2002) critical thinking strategies in language teaching are considered as a level of reading comprehension or discussion skills when the learner is able to question and evaluate what is read or heard. MCPeck (1991) considers solving problems, evaluating what has been read, and integrating understanding with knowledge of the world as the various goals of reading. Farr and Conner (2004) believe by modeling, coached practice, and reflection, it is possible to teach students strategies that can help them think while they are reading.

In language teaching, reading is recognized as an activity that engages students more actively with materials in the target language and encourages a deeper processing of it, since it is considered to be a communicative process which conveys meaning from writer's to the reader's mind (Nuttal, 1996). Consequently, teachers employ several techniques and strategies through which they can maximize their learners' abilities in language learning.

One of the strategies which can effectively promote critical thinking and thus, can be used as a teaching tool in the classroom is debate. Through investigating arguments, debate allows students to enhance critical thinking (Roy \&Macchiette, 2005). Oman (2010) maintains that critical thinking through debate can provide a healthy atmosphere in 
which learners find the opportunity to talk, learn from each other, and come up with creative ways to justify their argument without any personal attacks in the classroom. Maiorana (1992) believes that debate as a teaching tool helps students develop specific skills including analyzing, synthesizing, and evaluating arguments. Additionally, the debate process incorporates critical thinking and a plethora of other skills including listening, researching, problem solving, reasoning, questioning, and communicating. Sidhu (2008) claims that classroom teacher can promote language proficiency by using debate as a critical thinking strategy. He also adds that "Objectives such as critical thinking, problem solving, enhancing self-esteem, and the art of communication are all merged in every aspect of debate-from its preparation to its presentation"( Sidhu, 2008, p.1)

Critical thinking as a common feature in the L2 classrooms has strong pedagogical support although there is relatively little empirical research in this field. Mendenhal and Johnson (2010) found that using a variety of learning strategies supported learners in fostering critical thinking and critical writing. Moreover, in his study, Lodewyk (2009) showed that learners were capable of making reasonable judgments when they were engaged in critical thinking strategies such as decision making, problem solving, and debating. Scott's (2008) case study on the perceptions of the students learning critical thinking through debates revealed that debate as a critical thinking strategy could help students with analyzing and presenting arguments.

Yet, there are some researchers who question the efficacy of debate in classroom environment. Hill (1993) maintains that although critical thinking is assumed as an educational outcome acquired by participating in competitive debate, there is not sufficient research finding to prove that participating in competitive debate boosts development of critical thinking ability to any significant degree. Willingham (2007) argues that teaching critical thinking skills is too demanding, and only confuses students; he believes that possessing knowledge on the relevant content and thinking about it continuously are two crucial factors in ability to think critically. Case studies conducted by Yadav andBeckerman (2009) on teaching critical thinking and problem solving students to the undergraduate students of science education do not clearly signify whether the teaching method has the desired impact on the students'critical thinking in pathology courses.

Nevertheless, the present study examined the role of using debate as a critical thinking strategy on reading comprehension ability and also its effect on the development of the critical thinking ability of Iranian EFL learners. In order to achieve this goal the following research question was proposed:

Q: Does debate as a critical thinking strategy have any statistically significant impact on the development of critical thinking and reading comprehension abilities of Iranian EFL learners?

\section{METHOD}

\section{A. Participants}

The participants of the present study were 40 Iranian intermediate EFL learners aged between 18 and 25 years who were taking a reading course at Islamic Azad University, North Tehran Branch. The learners were selected based on convenient sampling and were randomly assigned to control and experimental groups.

\section{B. Instrumentation}

To homogenize the participants of the study regarding their general language proficiency, the standardized TOEFL test was used. Also, the reading section of the TOEFL test was utilized as an independent test to signify whether there was any significant difference in terms of the reading ability of the learners prior to the study. The TOEFL test consisting 55 multiple choice items on the English structure and reading comprehension was piloted with a group of 30 students similar to those of the target sample before the main administration. The item facility (IF) and item discrimination (ID) of the items were calculated and the items with appropriate range of IF (beyond 0.40) and ID (items with facility indexes between 0.63 and 0.37 ) were selected. Following the piloting process and discarding the malfunctioning items, 46 multiple choice items were selected for inclusion in the test. Afterwards, the internal consistency of the test was calculated through Kudar-Richardson Formula (KR-21), the result (r=0.78) indicating a relatively high reliability index.

Furthermore, a reading comprehension test was given to the participants of both control and experimental groups as the posttest to measure their reading comprehension after the treatment. The test was developed based on Longman's complete course for the TOEFL test. The readability of the reading passages in the posttest was computed through Microsoft Office Flesch Reading Ease and contrasted with the participants' text book. The average readability of the selected texts (70.1) was close to that of the pretest (73.8).

The IF and ID of each item was calculated and the malfunctioning items were discarded. Subsequently, the test consisting of 26 multiple choice type items were piloted with a group of 30 students similar to those of the target sample and its reliability was estimated $(\mathrm{r}=0.94)$ and was administered as the posttest in both experimental and control groups at the end of semester.

The third instrument used in the study was a critical thinking questionnaire constructed by Honey (2005). This questionnaire was piloted with a group of 30 students similar to those of the target sample before the main administration. The internal consistency of the questionnaire calculated through Cranach's Alpha $(r=0.78)$ indicated internal consistency of the questionnaire. The questionnaire including 30 Likert type questions each followed by five 
alternatives including Never(1), Rarely(2), Sometimes(3), Often(4), and Always(5)was used to measure the critical thinking ability of the participants before and after the treatment. Each testee's score could range from 30 to 150 .

\section{Procedure}

Initially, in order to check the homogeneity of the two groups, 55 learners in two intact classes took the standardized English proficiency test. Afterward, those students whose scores fell within the range of one standard deviation below and above the mean were considered as the participants of the study. The rationale behind the administration of the TOEFL test was to ensure that there was no significant difference in terms of the language proficiency of the participants prior to the study.

Subsequently, a reading pretest was given to both the experimental and control groups to measure their reading comprehension ability before the treatment $(\mathrm{k}=26, \mathrm{r}=0.68)$.In the next step, the participants in the experimental and control groups were asked to fill in Honey's (2005) critical thinking questionnaire.

\section{Instructinal Materials}

The course book used in this text was Reading for Ideas, Reflective Reader (Shokouhian, FotovatAhmadi, \&Khoii, 2006) containing eight units, each unit beginning with a reading passage and then moving on to some comprehension questions, true false questions, and tests of vocabulary.

\section{E. Treatment}

The treatment took 15 sessions each session lasting for 90 minutes. The process of teaching in each of the groups was as follows:

\section{F. Experimental Group}

The participants in the experimental group had eight texts to work on through debate and discussion. Each session started with a warm up. The teacher introduced the topic of the reading to the students, and tried to teach the unknown words to the studentsthrough discussions. At this stage, the teacher posed some questions and about 10 minutes were allocated tobrainstorming and discussing ideas. Then the students began to talk together and with the teacher to negotiate ideas. At this stage, the teacher presented the necessary words to the learners through discussion, and asked the students to read the text and answer the reading comprehension questions. Moreover, the teacher posed some further questions based on the topic of the reading passage and the students were asked to discuss them in groups. During the group discussions, the students were asked to present their ideas, and provide a summary of the reading text at the end of the class.

\section{G. Cotrol Group}

The participants in thecontrol group studied the same reading texts as the experimental group. However, the variable of discussions was eliminated in this group. The teacher presented a general warm up on the topic of the reading without posing any further questions for discussions before the reading. Then, the teacher asked one or more students to read the texts loudly, while the teacher presented the meaning of the unknown words to the students. After presenting the reading and the meaning of the new words, the students were asked to answer the questions following the text as well as to present a summary of the reading passage. No discussions were used after correcting the reading comprehension questions.

\section{H. Administering the Reading Posttest}

After the treatment, the reading comprehension posttest as well as the critical thinking questionnaire was administered to the participants in both groups. In order to test the null hypothesis, Multivariate Analysis of Variance (MANOVA) was run as the study aimed to examine the impact of debate as a critical thinking strategy (independent variable) on the learners' reading comprehension and critical thinking abilities (two dependent variables).

\section{RESULTS}

Prior to the study, the TOEFL test was piloted at Islamic Azad University, North Tehran Branch with a group of 30 examinees whose characteristics were similar to those of the target group. The purpose behind piloting the test was to estimate its reliability and to discard the inappropriate items. The reliability index of the TOEFL test $(r=.82)$ showed a high value. Table 1 below shows the descriptive statistics on the TOEFL proficiency test.

TABLE 1.

DescriPtive StAtistics ON PILOTING THE TOEFL TEST

\begin{tabular}{|l|l|l|l|l|l|l|l|l|l|l|}
\hline \multirow{2}{*}{ Group } & N & Range & Minimum & Maximum & Mean & SD & V & \multicolumn{2}{|l|}{ Skewness } \\
\cline { 4 - 11 } & & & & & & & & Statistics & Std. Error \\
\hline Piloting TOEFL test & 30 & 11 & 23 & 34 & 28.70 & 3.14 & 9.87 & -0.325 & 0.427 \\
\hline
\end{tabular}




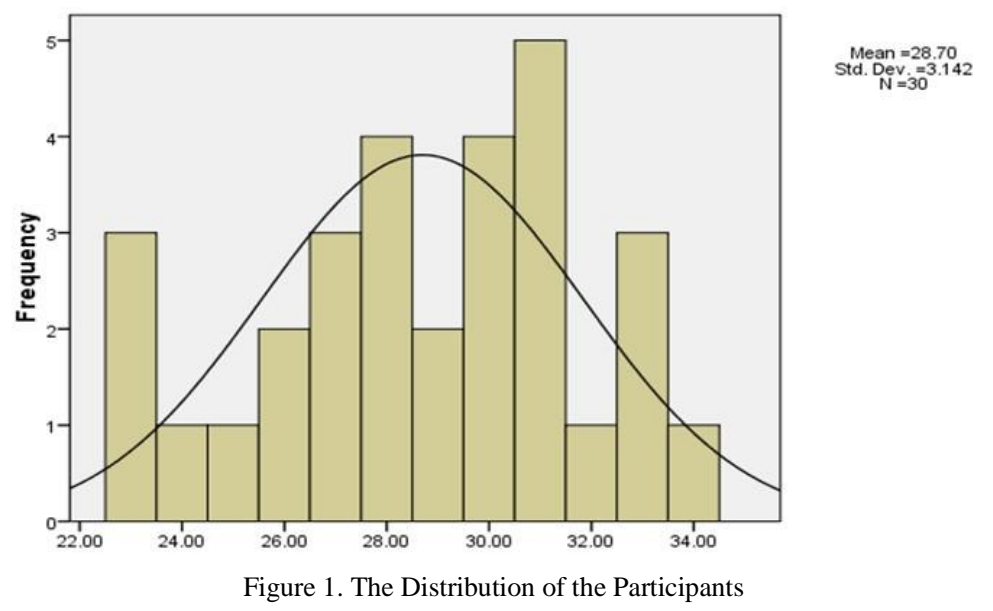

At the next step, the reading comprehension section of the TOEFL test was administered to a group of 30 examinees at Islamic Azad University, North Tehran Branch with characteristics similar to those of the target group. The purpose behind piloting was to examine the test's reliability and to discard the malfunctioning items. Table 2 illustrates the results of the descriptive statistics. The reliability index of the reading posttest $(0.94)$ showed a high value.

TABLE 2.

DESCRIPTIVE STATISTICS OF PILOTING THE READING POSTTEST

\begin{tabular}{|l|l|l|l|l|l|l|l|l|l|}
\hline \multirow{2}{*}{ Group } & $\mathrm{N}$ & Range & Minimum & Maximum & Mean & SD & V & \multicolumn{2}{|l|}{ Skewness } \\
\cline { 5 - 11 } & & & & & & & & Statistics & Std. Error \\
\hline Piloting Group & 30 & 10 & 20 & 30 & 26.13 & 3.08 & 9.49 & -0.248 & 0.427 \\
\hline
\end{tabular}

Furthermore, the questionnaire was piloted with the same group before the main administration and its reliability was calculated through Cronbach's Alpha $(r=0.78)$ which signified the reliability of the questionnaire. Table 3 illustrates the results of the descriptive statistics for piloting the questionnaire.

TABLE 3.

DESCRIPTIVE STATISTICS ON PILOTING CRITICAL THINKINGQUESTIONNAIRE

\begin{tabular}{|l|l|l|l|l|l|l|l|l|l|}
\hline Group & $\mathrm{N}$ & Range & Minimum & Maximum & Mean & SD & V & \multicolumn{2}{|l|}{ Skewness } \\
\cline { 5 - 10 } & & & & & & & Statistics & Std. Error \\
\hline Piloting Group & 30 & 65 & 65 & 130 & 1.0093 & 19.39 & 376.34 & -0.224 & 0.427 \\
\hline
\end{tabular}

The modified version of the TOEFL was given to 55 intermediate EFL learners in two intact classes at Islamic Azad University, North Tehran Branch. The objective was to examine the homogeneity of the two groups prior to the advancement of the study. A cut-point of one standard deviation above and below the mean was set and 40 learners (each group consisting of 20 students) whose proficiency scores were within this range were selected as the participants of the study. The results of the skewness analysis, as it is signified in table 4, obtained by dividing the statistic of skewness by the standard error revealed that the assumption of normality was observed in the distribution of the scores ( 0.87 for the experimental group, 1.61 for the control group, both of the indexes falling within the range of -1.96 and $+1.96)$.

Subsequently, an independent samples t-test was run to check whether there was any significant difference between the means of the two groups. As illustrated in Table 5, the two groups turned out to have homogeneous variances, $F=0.19, p=0.892$ (one- tailed). Therefore, with equal variances assumed, the $t$-test results indicated that there was no significant difference between the mean scores of the two groups on the TOEFL test, $t(38)=2.28, p=0.743$ (two - tailed) and thus, the two groups were proven to be homogeneous belonging to the same population. Finally the two classes were randomly assigned to the experimental and control groups of the study.

TABLE 4.

THE DESCRIPTIVE STATISTICS OF THE EXPERIMENTAL AND CONTROL GROUPS IN THE TOEFL TEST

\begin{tabular}{|c|c|c|c|c|c|c|c|c|c|}
\hline \multirow{2}{*}{ Groups } & \multirow{2}{*}{$\mathrm{N}$} & \multirow{2}{*}{ Range } & \multirow{2}{*}{ Min. } & \multirow{2}{*}{ Max. } & \multirow{2}{*}{ Mean } & \multirow{2}{*}{$\begin{array}{c}\text { Std. } \\
\text { Deviation }\end{array}$} & \multirow{2}{*}{ Variance } & \multicolumn{2}{|c|}{ Skewness } \\
\hline & & & & & & & & Statistics & Std. Error \\
\hline Control Group & 20 & 10 & 23 & 33 & 28.55 & 3.11 & 9.73 & 0.446 & 0.512 \\
\hline Experimental Group & 20 & 15 & 19 & 34 & 28.200 & 3.56 & 12.69 & -0.826 & 0.512 \\
\hline
\end{tabular}


TABLE 5.

THE INDEPENDENT SAMPLE $T$-TEST THE PROFICIENCY TEST

\begin{tabular}{|c|c|c|c|c|c|c|}
\hline \multirow{4}{*}{$\begin{array}{c}\text { qual } \\
\text { variances } \\
\text { assumed }\end{array}$} & \multirow{2}{*}{\multicolumn{2}{|c|}{$\begin{array}{c}\text { Levene's test of } \\
\text { Equality of } \\
\text { Variances }\end{array}$}} & \multicolumn{4}{|c|}{ T-test for Equality of Means } \\
\hline & & & $\begin{array}{c}\mathrm{T} \\
\text { observed }\end{array}$ & df & $\begin{array}{l}\text { Sig. (2- } \\
\text { tailed) }\end{array}$ & $\begin{array}{c}\text { Mean } \\
\text { Difference }\end{array}$ \\
\hline & $\begin{array}{c}\mathrm{F} \\
\text { observed }\end{array}$ & Sig. & \multirow[t]{2}{*}{0.331} & \multirow[t]{2}{*}{38} & \multirow[t]{2}{*}{0.743} & \multirow[t]{2}{*}{0.350} \\
\hline & 0.19 & 0.892 & & & & \\
\hline
\end{tabular}

TABLE 6.

DESCRIPTIVE STATISTICS OF THE EXPERIMENTAL AND CONTROL GROUPS IN THE READING PRETEST

\begin{tabular}{|c|c|c|c|c|c|c|c|c|c|}
\hline \multirow{2}{*}{ Groups } & \multirow{2}{*}{$\mathrm{N}$} & \multirow{2}{*}{ Range } & \multirow{2}{*}{ Min. } & \multirow{2}{*}{ Max. } & \multirow{2}{*}{ Mean } & \multirow{2}{*}{ Std. Deviation } & \multirow{2}{*}{ Variance } & \multicolumn{2}{|c|}{ Skewness } \\
\hline & & & & & & & & Statistics & Std. Error \\
\hline Experimental Group & 20 & 9 & 13 & 22 & 16.65 & 2.56 & 6.55 & 0.309 & 0.512 \\
\hline Control Group & 20 & 8 & 12 & 20 & 15.80 & 2.37 & 5.64 & 0.369 & 0.512 \\
\hline
\end{tabular}

The reading comprehension section of the TOEFL test served as the pretest of the study. Reading pretest was given to both the experimental and control groups to measure their reading comprehension ability before the treatment. In addition, the reliability index of the reading test ( $\mathrm{r}=.68$ ) showed a high value. The above table describes the descriptive statistics of the control and experimental groups in the pretest. As it is demonstrated, there is no difference between the pretest mean scores of control and experimental groups, and two groups are homogeneous. Table 7 signifies the descriptive statistics of the control and experimental groups in the posttest.

TABLE 7.

DESCRIPTIVE STATISTICS OF THE READING POSTTEST

\begin{tabular}{|c|c|c|c|c|c|c|c|c|c|}
\hline Groups & N & Range & Min. & Max. & Mean & $\begin{array}{c}\text { Std. } \\
\text { Deviation }\end{array}$ & Variance & \multicolumn{2}{|c|}{ Skewness } \\
\cline { 4 - 10 } & & & & & & 26 & Statistics & Std. Error \\
\hline Experimental Group & 20 & 8 & 18 & 26 & 22.90 & 2.77 & 7.67 & 0.314 & 0.512 \\
\hline Control Group & 20 & 13 & 13 & 26 & 18.60 & 4.14 & 17.20 & 0.552 & 0.512 \\
\hline
\end{tabular}

TABLE. 8.

DESCRIPTIVE STATISTICS OF CRITICAL THINKING PRETEST (EXPERIMENTAL AND CONTROL GROUPS)

\begin{tabular}{|c|c|c|c|c|c|c|c|c|c|}
\hline Groups & $\mathrm{N}$ & Range & Minimum & Maximum & Mean & $\begin{array}{c}\text { Std. } \\
\text { Deviation }\end{array}$ & Variance & \multicolumn{2}{|c|}{ Skewness } \\
\hline Control Group & 20 & 63 & 60 & 123 & 89.450 & 4.125 & 18.45 & 0.247 & 0.512 \\
\hline Experimental Group & 20 & 60 & 78 & 138 & 15288 & 4.77 & 252.20 & -0.451 & 0.512 \\
\hline
\end{tabular}

Table 8 describes the descriptive statistics of the control and experimental groups in the critical thinking pretest. Table 9 describes the descriptive statistics of the control and experimental groups in the critical thinking posttest.

TABLE 9.

\begin{tabular}{|c|c|c|c|c|c|c|c|c|c|}
\hline \multicolumn{10}{|c|}{ DESCRIPTIVE STATISTICS OF CRITICAL THINKING POSTTEST (CONTROL AND EXPERIMENTAL GROUPS) } \\
\hline \multirow{2}{*}{ Groups } & \multirow{2}{*}{$\mathrm{N}$} & \multirow{2}{*}{ Range } & \multirow{2}{*}{ Min. } & \multirow{2}{*}{ Max. } & \multirow{2}{*}{ Mean } & \multirow{2}{*}{$\begin{array}{c}\text { Std. } \\
\text { Deviation }\end{array}$} & \multirow{2}{*}{ Variance } & \multicolumn{2}{|c|}{ Skewness } \\
\hline & & & & & & & & Statistics & Std. Error \\
\hline Control Group & 20 & 65 & 55 & 120 & 87 & 21.17 & 448.421 & 0.240 & 0.512 \\
\hline Experimental Group & 20 & 72 & 55 & 127 & 88.35 & 21.36 & 456.55 & 0.173 & 0.512 \\
\hline
\end{tabular}

Within subject factors including pre and posttests on reading as well aspre and posttest on critical thinking questionnaire are demonstrated in table 10 below. Besides, Table 11 shows between subject factors including control and experimental groups.

TABLE 10

WITHIN -SUBJECT FACTORS

\begin{tabular}{|l|l|}
\hline Factor 1 & Dependent Variable \\
\hline 1 & Pretest Reading \\
2 & Posttest Reading \\
3 & Post Critical Thinking Questionnaire \\
4 & Pre Critical Thinking Questionnaire \\
\hline
\end{tabular}


TABLE 11

BETWEEN- SUBJECT FACTORS

\begin{tabular}{|l|l|l|}
\hline & Value Label & $\mathrm{N}$ \\
\hline Groups 1.00 & Experimental & 20 \\
2.00 & Control & 20 \\
\hline
\end{tabular}

The discriptive statistics for both of the groups on reading and critical thinking questionnaires are shown in Table 12 below:

TABLE 12.

DESCRIPTIVE STATISTICS FOR CONTROL AND EXPERIMENTAL READING AND CRITICAL THINKING PRE AND POST TESTS

\begin{tabular}{|l|l|l|l|}
\hline Group & Mean & Std. Deviation & N \\
\hline Pretest reading experimental & 16.65 & 2.56 & 20 \\
Control & 15.80 & 2.37 & 20 \\
Total & 16.22 & 2.47 & 40 \\
\hline Posttest reading experimental & 22.90 & 2.77 & 20 \\
Control & 18.65 & 4.10 & 20 \\
Total & 20.77 & 4.07 & 40 \\
\hline Post critical thinking experimental & 112.1 & 15.88 & 20 \\
Control & 89.45 & 18.45 & 20 \\
Total & 100.7 & 20.50 & 40 \\
\hline Pre critical thinking experimental & 88.35 & 21.36 & 20 \\
Control & 87.00 & 21.17 & 20 \\
Total & 87.67 & 21.00 & 40 \\
\hline
\end{tabular}

It was necessary to check for Homogeneity of intercorrelations to see if for each of the levels of the between-subject variable (i.e. type of treatment) the pattern of intercorrelation among the levels of within- subjects variables (i.e. reading and critical thinking) were the same. To test this assumption, Box's M statistic with the more conservative alpha level of .001 was used with the hope that the statistic would not be significant (i.e. that the p level would be greater than 0.001). In other words, Box's M statistic tested the null hypothesis that the observed covariance matrices of the dependent variables were equal across groups. Table 13 displays the result and indicates that this assumption was met $(\mathrm{Sig}=0.009)$.

TABLE 13.

BOX's TEST OF EQUALITY OF COVARIANCE MATRICES

\begin{tabular}{|l|l|}
\hline Box's M & 26.660 \\
F & 2.360 \\
Df1 & 10 \\
Df2 & 6903.58 \\
Sig. & 0.009 \\
\hline
\end{tabular}

A look at the Multivariate Tests table also indicated that there was a change in the reading performance and critical thinking of the participants. There was an indication that the two groups were different in terms of their reading performance and critical thinking ability. These findings are illustrated by Wilks' Lambda values and the associated probability values given in the column labeled Sig. in Table 14.As the table displays, the value for Wilks' Lambda for debate is 0.963 , with a Sig. value of $0.000<0.001$. Since the value for $p$ is lesser than 0.05 , it can be concluded that there is a statistically significant effect for debate. This suggests that there was a change in the reading comprehension and critical thinking abilities of the participants of the study after the treatment. Thus, the main effect for debate was significant. The eta squared value for debate (Table14) is 0.963 showing a large effect size (utilizing the commonly used guidelines proposed by Cohen, 1988, pp.284-7, 0.01=small effect, 0.06= moderate effect, 0.14= large).

TABLE 14.

Multivariate TeST

\begin{tabular}{|l|l|l|l|l|l|l|}
\hline Effect & Value & F & Hypothesis df & Error df & Sig & Partial eta Squared $\left(\eta^{2}\right)$ \\
\hline Debate Pillai's Trace & 0.963 & 316.543 & 3.000 & 36.00 & 0.000 & 0.963 \\
Wilks' Lambda & 0.037 & 316.543 & 3.000 & 36.00 & 0.000 & 0.963 \\
\hline Debate Pillai's Trace Wilks' Lambda & 0.455 & 10.00 & 3.00 & 36.00 & 0.000 & 0.455 \\
Group & 0.545 & 10.00 & 3.00 & 36.00 & 0.000 & 0.455 \\
\hline
\end{tabular}


TABLE 15.

TESTS OF Within AND BETWEEN SUBJeCts' EFFECTS

\begin{tabular}{|l|l|l|l|l|l|l|}
\hline Source dependent variable & Type III Sum of Squares & df & Mean Square & F & Sig & Partial eta Squared \\
\hline Groups Pretest reading & 7.22 & 1 & 7.225 & 1.185 & 0.283 & 0.030 \\
Posttest reading & 180.62 & 1 & 180.625 & 14.718 & 0.000 & 0.279 \\
Post critical thinking & 5130.22 & 1 & 5130.225 & 17.312 & 0.000 & 0.313 \\
Pre critical thinking & 18.22 & 1 & 18.225 & 0.040 & 0.842 & 0.001 \\
\hline Error Pretest reading & 231.750 & 38 & 6.099 & & & \\
Posttest reading & 466.350 & 38 & 12.272 & & & \\
Post critical thinking & 11260.750 & 38 & 296.336 & & & \\
Pre critical thinking & 17194.550 & 38 & 452.488 & & & \\
\hline Total Pretest reading & 10769.000 & 40 & & & & \\
Posttest reading & 17911.000 & 40 & & & & \\
Post critical thinking & 4226.15 & 40 & & & & \\
Pre critical thinking & 324689.000 & 40 & & & & \\
\hline
\end{tabular}

As can be observed in table 15 , the Sig. value in the pretest reading is $0.283>0.05$, so it can be concluded that there was no significant difference between the control and experimental groups in the reading pretest $(\mathrm{f}=7.225)$. The partial eta squared value for group in this case is 0.030 which is a small effect. Nevertheless, the Sig. value in the posttest reading is 0.000 and thus it can be concluded that there was a significant difference between the control and experimental groups in the reading posttest $(\mathrm{f}=180.62)$. The effect size, using eta squared is 0.279 which indicates a relatively large effect size, which means that debate by itself accounted for almost $28 \%$ of the overall variance which is a large effect size.

Moreover, the Sig. value in the pretest critical thinking is $0.842>0.05$, showing that there is no significant difference between the control and experimental groups in the critical thinking pretest $(\mathrm{f}=18.225)$. The partial eta squared value for group in this case is 0.001 which signifies a very small effect size. However, the Sig. value in the posttest of the critical thinking is $0.000<0.05$, signifying that there is a significant difference between the control and experimental groups in the critical thinking posttest $(\mathrm{f}=180.62)$. The effect size computed through eta squared is $\left(\boldsymbol{\eta}^{2}=0.313\right)$ illustrating that $31 \%$ of the overall variance is due to the independent variable (debate).

TABLE 16.

TESTS OF BETWEEN-SUBJECTS EFFECTS

\begin{tabular}{|l|l|l|l|l|l|l|}
\hline Source & Type III Sum of Squares & df & Mean Square & F & sig & Partial Eta Squared \\
\hline Intercept & 508277.025 & 1 & 508277.025 & 1733.496 & 0.000 & 0.979 \\
Groups & 2117.025 & 1 & 2117.025 & 7.220 & 0.011 & 0.160 \\
Error & 11141.950 & 38 & 293.209 & & \\
\hline
\end{tabular}

As can be observed in this table, the $p$ value is $0.000<0.05$ and thus, there is a significant difference between the two groups; that is, the control group, who didn't received the treatment and the experimental group, who received the treatment. Hence, it can be concluded that debate had a significant impact on the learners' reading and critical thinking abilities $(\mathrm{f}=7.22 ; \mathrm{p}<0.05)$.

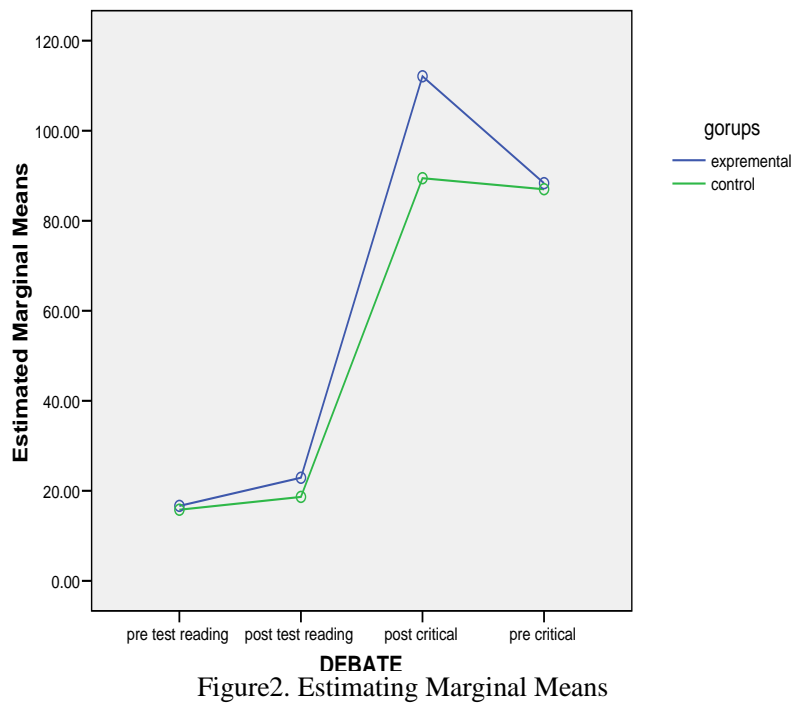


The result shows that there was no significant difference between the two groups' pretest scores, and both had the same means. However, there were significant differences between the posttests of the two groups; the mean of the experimental group being higher than the mean of the control group.

\section{DISCUSSION}

This study was an attempt to explore the effect of debate as a critical thinking strategy on the reading comprehension ability of Iranian EFL learners. It was found that there was a significant difference between the experimental and control groups' performances on the posttest which could be due to the intervention in the experimental group. The results of the study, could lead the researchers to conclude that using debate as a strategy can improve the reading comprehension and critical thinking of the participants of the study.

The results of the study showed that English classes could help students improve their thinking skills. Since critical thinking strategies are demanding and difficult to learn, it is quite possible to facilitate their learning by getting students involved in language skills such as reading. As Snow (2002) maintains, writers cannot possibly make all the information explicit in the text so they rely on the readers to make necessary inferences in each case. Therefore, readers may not grasp the intended points without appropriate thinking strategies. By encouraging students to discuss different aspects of the reading material, they reflect on it, make judgments, and finally defend their position. Moreover, the finding of this study is in line with Freely and Steinberg (2000) who highlight the importance of debates as a strategy which contributes to enhancing critical thinking. Through debates learners try to combine the academic content to their life experiences and hence, improve their language skill as well as improve their critical thinking ability.

\section{CONCLUSION}

The finding from this study provides some implications for language teachers, learners, and teacher trainers. Debate as a critical thinking strategy enhances learners' inferential abilities and also fosters their deep understanding of the written text. It enables them to grasp and examine the potential implications within the text and read between the lines and also it helps learners to challenge the source of the knowledge and even themselves. Practicing critical thinking changes the learners from passive receivers of the new materials in to critical thinkers.

\section{REFERENCES}

[1] Chaffee, J. (2009). Thinking critically. Boston, MA: Heinle. critical thinking skills of marketing students. Journal of Marketing Education. 27(3).264-276.

[2] Farr, R., \& Conner. J. (2004). Using think-aloud to improve reading comprehension. Retrieved November 10, 2010, from File://A:/peterhoney com $\% 20 \% 20$ critical $\% 20$ thinking $\% 20$ questionnaire.htm.

[3] Freely, A. J., \& Steinberg, D. L. (2000). Argumentation and debate: Critical thinking for reasoned decision making. Stamford: Wadsworth.

[4] Halpern, D. F. (1996).Thought and knowledge: An introduction to critical thinking (Third edition). Mahwah, NJ: Lawrence Erlbaum Associates, Inc.

[5] Hill, B. (1993). The value of competitive debate as a vehicle for promoting development of critical thinking ability. CEDA Yearbook 14, 1-22.

[6] Honey, p. (2005). Critical thinking questionnaire. Retrieved November 21, 2007 from http://www .readingrockets.org/article/c67/?start

[7] Lodewyk, K. (2009). Fostering critical thinking in physical education students. Journal of Physical Education, Recreation\& Dance (JDPERD), 80 (8), 12-18

[8] Maiorana, V.P. (1992). Critical thinking across the curriculum: Building the analytical Classroom. Bloomington, IN: Eric Clearinghouse.

[9] Mangel, P. (2005). Advanced educational psychology (2 $2^{\text {nd }}$ ed.). New Delhi: Prentice Hall of India.

[10] McPeck, J. E. (1991). Critical thinking and education. NY: St. Martin's Press.

[11] Mendenhal, A., \& Johnson, T. (2009). Fostering the development of critical thinking skill and reading comprehension. East Lancing, MI: Educational Resources Information Center. (ERIC Document Reproduction Service No. EJ893964)

[12] Nuttal, C. (1996). Teaching reading skills in a foreign language. London: Longman.

[13] Oman, J. (2010). Teaching critical thinking through debate. Retrieved January 24, 2011 from http://www.suit101.com/content/teaching-critical -thinking-a229509.

[14] Paul. R., \& Elder. L. (2006).The miniature guide to critical thinking concepts and tools. CA: the Foundation for Critical Thinking.

[15] Richards, J.C., \& Schmidt, R. (2002). Longman dictionary of language teaching and applied linguistics. London: Pearson Education.

[16] Roy, A., \& Machiette, B. (2005). Debating the issues: A tool for augmenting critical thinking skills of marketing students. Journal of Marketing Education. 27(3), 264-276.

[17] Santrock, J.W. (2008). Educational Psychology ( $3^{\text {rd }}$ ed.). NY: MacGraw Hill.

[18] Scott, S. (2008). Perceptions of students' learning critical thinking through debate in a technology classroom. Journal of Technology Studies 7(1), 39-44.

[19] Shokouhian, M., FotovatAhmadi, P., \& Khoii, R. (2006). Reading for ideas, reflective reader. Tehran: Rahnama Publications.

[20] Sidhu, J.K. (2008). Debate- a fundamental tool in developing language proficiency. Retrieved December 14, 2010 from 
reading rockets. Org./article/c67/?start.

[21] Snow, C. (2002). Reading for understanding. Pittsburgh: Rand Education.

[22] Willingham, D.T. (2007). Critical thinking: Why it is so hard to teach? American Educator, summer, 8-19.

[23] Yadav, A., \& Beckerman, J. L. (2009).Implementing case studies in a plant pathology course: Impact on student learning and engagement. Journal of Natural Resources and Life Sciences Education, 38,50-55.

Mojgan Rashtchi was born in Tehran, Iran in 1961. She received her PhD in Applied Linguistics from Islamic Azad University, Science and Research Branch in 1998.

She is currently the Head of Graduate TEFL Department at Islamic Azad University, North Tehran Branch, Iran and has been teaching at undergraduate and graduate levels in the areas of language teaching methodology, research, and language skills. She has published several articles and books on teaching English to children and adults. Her main areas of interest include issues of first language acquisition and exploring teaching techniques to children and adults.

Fatemeh Sadraeimanesh was born in Tehran, Iran in 1969. She has recently received her MA degree in TEFL from Islamic Azad University, North Tehran Branch.

She has been teaching English to children and adults in different language institutes including Iran National Institute. 